https://doi.org/10.31426/ijamsr.2018.1.10.1021

\begin{tabular}{l|l} 
International Journal of \\
I J A M S R
\end{tabular} Advanced Multidisciplinary Scientific Research (IJAMSR) ISSN:2581-4281

\title{
IBN-KHALDUN'S PERCEPTION OF EDUCATION: PRE-CONDITIONS AND EXCELLENCE
}

\author{
Khursheed Ahmad Khanday \\ Research Scholar, Dept. of. Education, Kashmir University, Kashmir, India
}

Email: khursheed5100@gmail.com

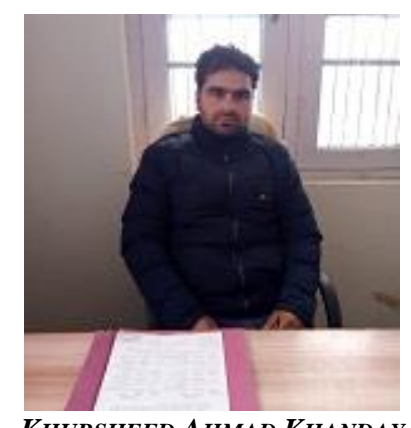

KHURSHEED AHMAD KHANDAY

Keywords: IBN -Khaldun's, Concept of Education, preconditions, excellence.

\section{Introduction}

In the contemporary century witness great changes in the fields of knowledge and technology which in turn made most educational systems everywhere amend and

\begin{abstract}
A B S T R A C T
The present study aimed to shed some light on the excellence of education and its preconditions. According to IBN -Khaldun through linking his philosophy to the contemporary studies on one hand, and to the present condition in today's schools. To achieve these objectives, the qualitative approach was employed through using the content analysis method to scrutinize IBN -Khaldun's Muqaddimah so as to extract the most relevant and recent educational trends in this prominent book. The researcher concluded with the idea that IBN - Khaldun was able to found a clear pedagogical philosophy when he set major pre-conditions for learning which in turn leads to minor pre-conditions that work together to enhance the learner's endowment and talent that contribute to learning. Furthermore, the content-analysis of Al-Muqaddimah revealed that IBN-Khaldun provided educational measures and concepts that paved the way for the modern educational theories relevant to methods of teaching and educational psychology which in turn contributed to the recent improvement in today's educational organization.
\end{abstract}

Citation: Khursheed Ahmad Khanday (2018). IBN-Khaldun's Perception of Education: Pre-Conditions and Excellence. International Journal of Advanced Multidisciplinary Scientific Research (IJAMSR) ISSN:2581-4281 Vol 1, Issue 10, December, 2018, \#Art.1021, pp 95-106 


\section{International Journal of Advanced Multidisciplinary Scientific Research (IJAMSR) ISSN:2581-4281}

still considered one of the most pioneering educators who provided the educational thought with practical and indispensible methodological prolegomena that aim for the worth of education.

Ibn-Khaldun, who was born in Tunisia in 1332 and died in 1406, is the clued-up Imam Abdul-Rahman bin Muhammed bin Muhammed. He was named Ibn Khaldun after one of his grandfathers and grew up in a family that combined knowledge and influence. Ibn Khaldun learnt the Holy Koran by heart when he was very young when his father was his first tutor. Afterwards, he obtained knowledge from philosophers and Imams of Koran, Hadith, Language and Literature. He excelled in different fields and thus became very famous especially in rhetoric, education and philosophy although he had not turned 20 years old yet (Al-Sayyed, 2005:180). He was then the Head Judge of Malikiya which was the highest point a person can obtain at that time (Akkawi, 1998:28).

Ibn-Khaldun is still occupying a prominent position not only in the Arab and Islamic world but also in the whole globe due to his distinct educational, intellectual and cultural perspectives which significantly contributed to the planning of today's strategic educational policies everywhere. In this regard, Al-Khaldi (2011: 322) avers that Ibn-Khaldun was well-known for his scientific research in addition to his famous writings, one of which is Al-Muqaddimah "The Introduction “ . Meanwhile, Ibn-Khaldun's contributions were not restricted to his descriptive methodology because he was concerned with the specific details of the different pedagogical practices through employing a practical and critical approach that excelled the prevailing knowledge standards at his time. Education, according to Ibn-Khaldun, is seen as a social process in terms of its overall essence, content, function and objectives to the extent that this process cannot be separated from the society especially when it is the means to express individual' needs on one hand and the society needs on the other hand (Alwani, 2006).

Ibn -Khaldun believes that teaching and learning are natural phenomena in the human beings structure and that education resembles one form of industries which reveals that education as a profession cannot by any means be an abstract entity but it should be based on experimentation, training and experiential practice since one cannot acquire a craft without practicing it for a long time (Ibn-Khaldun, 2001).

Haddad (2011) maintains that Ibn-Khaldun seeks to set the basics of teaching and learning by emphasizing the teacher-learner-content bond as a reaction to the nature of humanity which is always eager to learn and obtain knowledge so as to achieve civilization and constructional changes as pre-conditions for effective teaching and learning. By the same token , Awamreh (2014) indicates that Ibn-Khaldun aimed to address all spheres of knowledge and that his educational perspectives are considered to be the basics of contemporary educational strategies nowadays. Hence, Ibn-Khaldun is seen as the pioneer of many pedagogical theories and educational psychology especially when his theories and insights were meant for helping teachers to adopt repetitive sequenced methods when presenting the teaching material so as to trigger a kind of motivation and interest in the educational process that leads to effective learning. Thus, it seems that Ibn-Khaldun was concerned with education as a whole and the particular educational elements including the teacher, the learner, the curriculum, the environment and the pedagogy as well. 


\section{International Journal of Advanced Multidisciplinary Scientific Research (IJAMSR) ISSN:2581-4281}

According to Al-Bahi and Fiadh (2009), education is the basic means for cultural development of any society while Sheetah (2007: 373) defines education as transferring knowledge to learners, building experiences and practices, imparting values and sciences among learners. On the other hand, Ibn-Khaldun believes that education is strongly related to the human innate nature when Allah created man to have a brain used for constant thinking (Ibn-Khaldun, 2001). Furthermore, Ibn-Khaldun believes that education is a learned art by itself as it can be acquired through exerting continuous efforts and experiential practices which implies that the educational process requires mastery of proficiency and skillfulness. Therefore, Ibn-Khaldun maintains that proficiency and skillfulness means having the talent for mastering the basic components and elements of science, understanding its controversial issues and deducing its subdivisions out of its basic principles. If such talent was missing, there will be neither proficiency nor skillfulness. Thus, such talent is something beyond comprehension and awareness (Ibn-Khaldun , 2001 : 543). This may indicate that comprehension is only one stage of the talent processing since achieving constant and stable mastery of a given discipline is a natural output of many mental process and sequenced methodology. These stages and processes can be represented in the following diagram according to Adman and Mahmud (2014):

\section{Mastery of Rules and Principles + Thinking and Speculation + Deduction $\rightarrow$ Talent}

The aforementioned discussion reveals that the current pedagogical concepts are not far away from IbnKhaldun's concept of education as he believes that education is a respectable high class industry. Accordingly, the present study aimed at exploring the most obvious components in Ibn-Khaldun's approach of education in terms of pre-conditions for learning, procedures and pedagogical practices relevant to quality of education so as to arrive at some suggestions and recommendations that can be used to evaluate the current educational situation in our schooling system nowadays.

\section{Objectives of the Study}

The present study aims at identifying the most apparent educational concepts in Ibn Khaldun's thought and his perspectives of the pre-conditions of learning. Moreover, the study aims to explore the pedagogical practices relevant to the quality of education as perceived by IbnKhaldun and how to make use of them to enhance learning and to achieve the quality of education we seek.

\section{Statement of the Problem and Questions of the Study}

The kind of education which the new generation calls 'the new education' or 'modern education, is based on the work of many thinkers. Ibn Khaldun is one of the Muslim scholar and educationists who influence people worldwide through his thought. The main source of knowledge according to Ibn Khaldun is Quran and traditions; however he defined education in social and individual contents. So he specified the social and individual aims for physical and spiritual development of human beings. He stresses that information should be given to students from simple to complex, from lower level to higher so they can understand. If teaching methods are based on it the education will prove more effective. The level of students should be considered 


\section{International Journal of Advanced Multidisciplinary Scientific Research (IJAMSR) ISSN:2581-4281}

first, teacher should repeat the lecture that is recapitulation, should employ so as to enable taught to retain it in mind. The student should not force to read and drill but education should be imparted liberally without creating fear among students. For the learning and understanding of scientific subjects he emphasized learning skills. According to Iqbal and and Khaldun teacher should be liberal, practical and guiding philosopher which make students to learn properly. National discipline is allowed to prevail among students. He advises teachers to teach in a comprehensive manner at stages and levels moving from easier to complex. He dismissed and discouraged aggressive behavior towards children because it negatively affects the children. According to him education should consist of theory and practice and need to be revised and repeated until desirable level of learning is attained. He declares that learning of science requires skills. The teachers should be knowledgeable, practical and skillful in their respective fields. These clearly defined principles of education of Ibn Khaldun are yet relevant in the contemporary times but need to be explored so that they can carve niche in the educational system of India. These principles are clearly philosophical and need philosophical approach to incorporate them in educational system.

Ibn Khaldun's educational philosophy in the field of education gives insight to the teachers and administers on various educational problems related to the concept of education, Aims, Methods, content, curriculum teacher, discipline and administration pattern etc. which enable not only solve them at intellectual and philosophical level but also at practical level? The purpose is to see to what extent the educational views of these great philosophers are relevant to modern times. In the present study attempt is made to see how, Ibn Khaldun present his general and educational philosophy on education system and how it is related with present educational system. After reviewing literature on this subject, it is astonished to discover that there is no single book, which comprehensively reflects educational philosophies of Ibn Khaldun. There are lot of books, which contain educational thought of Ibn Khaldun but that, is broken in short passages or segments so, in present study attempt is made to present his educational philosophy.

The problem of the study can be summarized in one question: How does Ibn-Khaldun deal with the preconditions for education and its excellence? This question is then divided into three sub-questions as follows:

a) What are the pedagogical principles in IbnKhaldun's thought?

b) How does Ibn-Khaldun deal with the preconditions for education and learning?

c) What are the most significant ideas of IbnKhaldun with regard to the quality of education?

\section{Limitations of the Study}

The range of this study is restricted to the study of the perception of education in Ibn-Khaldun's consideration through probing the educational principles, the preconditions for knowledge and the excellence of education as professed by Ibn-Khaldun himself. 


\section{Methodology}

The methodology for the present study will be a combination of philosophical and historical method of research. The researcher gone through the, primary and secondary sources of data. Accordingly the data collected studied, Scrutinized and critically analyzed for interpretation and for drawing conclusions. Educational research contributes to human knowledge and human welfare it is an ongoing and never ending process that opens up new avenues related to human behavior and practices in educational settings. The nature of present study is philosophical as well as historical. It is philosophical in the sense that Ibn Kaldun's educational thought is analyzed and organized; it is historical because Ibn Khaldun was philosopher of different era so development of education from various sources has been traced. In this study Ibn Khaldun's own writing will be taken as primary sources, and works on this subject as secondary sources.

\section{Findings}

1-What are the pedagogical principles in IbnKhaldun's thought?

From Ibn Khaldun's point of view, learning is based on three pillars: the teacher, the learner and method of teaching. The achievement of the educational and learning goals is contingent on pre- conditions of the learning setting since learning generally involves knowledge and insights that stem from contemplation that seeks truth and facts. Accordingly, Ibn Khaldun Education relies on scientific bases that proceed from the following principles (Froukh, 1984):

\section{First Principle: Human Thought}

It is the thought that distinguishes man from other creatures. All sciences and crafts spring from this thought since man keeps thinking about himself, his surrounding world and the hereafter.

Second Principle: Teaching and Learning is Human in Nature

This indicates that teaching and learning is natural for humans. Thus, there is no knowledge outside the human society. Scholars found that when a human being leaves his tribe and nature, they lose this human property. What enhances this property is that it depends on thought and knowledge which do not exist outside the human society.

\section{Third Principle: Theoretical and Applied Competences}

Ibn Khaldoun considers education as a craft or industry. This suggests that one should obtain its theoretical and applied competences through training, practicing, studying and conducting research. Given that education is a craft, there should be a teacher who teaches students the competences, basics, knowledge and techniques of this craft.

Fourth Principle: The Relation of Knowledge and Science to the Physical World

Theorization stems from what is perceived or assumed . 
Knowledge is, then, a change of the actual world. Science does not suffice with counting inputs but aims at organizing them. It puts these inputs into certain orders and establishes relationships between their components in order to change them into a subject of science.

\section{How does Ibn-khaldun View Pre-Conditions for} Learning?

The educational act comes as an inevitable result of a two-sided objective: the first is to acquire the talent for mastering completely the material needed to by learnt according to the given pre-conditions. The second is to achieve the required objective of education which should be considered as a form of human activity that can serve the practical needs of our humanity. This is because there is a strong connection between the teaching act as a pedagogical activity done by the teacher and the learning act as a pedagogical effectiveness practiced by the learner. (Shams Eddeen, 1986). From the abovementioned discussion, some pre-conditions for learning can be mentioned as follows:

1) Nature of thought: Ibn -Khaldun believes that knowledge (learning ) and teaching are a natural phenomenon in human beings as a result of the human thought (mind) which distinguishes human beings from other creatures .(Sheikh Al-Ardh, 1984). This shows that Ibn-Khaldun realized that the nature of human thought usually hunts for knowledge and inquiry and therefore urges man to learn and acquire knowledge. Such idea shows that man is wired to learn, discover and achieve and these are the major pre-conditions for teaching and learning. (Haddad, 2011).

2) Urbanization and civilization: Ibn -Khaldun stipulates that for learning to occur ,there must be a kind of civilization and urbanization because education in general is greatly influenced by the level of social advancement as the high level of civilization and prosperity are essential means for the spread of sciences and industries (Sheikh Al-Ardh , 1984: 88). In this regard, Adman and Mahmud (2014) state that there is a direct relationship between the good quality of industries and civilization because sciences do not grow and progress without civilized environment and context . Undoubtedly, and under these pre-conditions, civilization and prosperity are seen to be key tools for developing and mastering industrialization. In this case the researcher avers that Ibn-Khaldun aimed to connect civilization and development with education believing that education is art and industry by itself and therefore art and industry cannot flourish without civilization and development.

3)Teacher: Ibn -Khaldun asserts that the teacher is an indispensible key component in the educational process and without teachers, learning will be difficult to succeed because the teacher bears the responsibility of delivering knowledge to students who necessarily need it(Ibn-Khaldun, 2001). The talent for learning cannot be enhanced in the absence of an effective teacher who is responsible for disseminating information and knowledge among learners. Therefore, Ibn -Khaldun asserts that teachers should have certain characteristics and traits such as being skillful and talented to be able to create the desire and the talent to learn among learners. 


\section{International Journal of Advanced Multidisciplinary Scientific Research (IJAMSR) ISSN:2581-4281}

In this regard, Ibn-Khladun states that “ The skillfulness and intelligence of learners greatly depend on the quality of education and the talent of the teacher" (IbnKhaldun, 2001: 501) .

Muhi (1991:27) indicates that a teacher is the person who performs the teaching act while Ibn-Khaldun identifies teacher's job through assigning a number of pedagogical processes, acts and procedures during the life circle of the teaching act for the purpose of fulfilling the objectives of this pedagogical act. Among the activities and roles that are assigned to the teacher are: presenting the lesson, observing the learning activities of students, controlling students' behaviors, maintaining discipline, introducing the lesson, choosing suitable content, choosing educational methods and approaches, planning methodological strategies for teaching and learning, presenting content knowledge through explanation and demonstration and through using sensory examples and proofing for demonstration and explanation.

While Haddad (2011) argues that teachers according to Ibn-Khaldun should have two major tasks; the introductory part and the performance part, Muhi (1991) argues that Ibn-Khaldun emphasizes the importance of content knowledge and pedagogical content knowledge for competent teachers to perform the educational activities which implies that Ibn-Khaldun stressed the importance of having a competent teacher who is highly qualified in terms of content knowledge, pedagogical content knowledge and educational knowledge as well. Hence, it seems that Ibn-Khaldun's perspectives and thoughts are in consistent with the current educational trends especially when Ibn-Khaldun assigns significant roles to the teacher who is the center of the teaching learning process. This point of view, however, might be contradictory to the current trends which considers the learner to be the center of the teaching-learning process in the so-called learner-centered approach which maintains that the learner is the key target of the educational process.

4) Learner: The learner is the one who receives the learning act (Muhi ,1991; Haddad, 2011) and his/her major task according to Ibn-Khaldun is restricted to receiving everything planned and given by the teacher through listening and writing down what he/she hears from that teacher so as to store and then recall information when needed.

5) Content (curriculum ): Traditionally, the curriculum is limited in scope to mean the textbook that emphasizes the content knowledge aspect. Therefore, the teacher's role is just to "disseminate " knowledge and information, explain the material and cover the content in a limited time while deemphasizing the non-curricular activities outside the classroom. Within this context, the teacher becomes book-bound while he/she becomes uninterested in helping learners to understand the surrounding environment on one hand, and develop his/her social values and attitudes on the other hand.(AlAlawani,2006). Ibn-Khaldun, meanwhile, asserts that the curriculum should be well-organized in accordance with certain principles that take into account the learners' abilities and their aptitudes. The content, accordingly, should follow a logical sequence and grading that moves from simple to more complex elements, from easy to 
difficult and form concrete elements to abstract elements.(Ibn-Khaldun, 2001).

Current literature review asserts that the contemporary curriculum should work towards achieving the behavioral objectives that need to precede the design of the curriculum and the strategies of teaching in addition to the assigned roles of both the teacher and the learners. In this regard, Ibn-Khaldun presents these levels and requirements in a precise and profound style that is particularly shown in the sixth chapter of AlMuqaddimah which is dedicated to discuss the issue of types sciences and methods of teaching as well.

6) Achieving talent development through learning: IbnKhaldun believes that the availability of the appropriate content with the teacher in addition to the suitable social and modernized environment will result in better educational achievement on one side, and acquiring the talent of learning on the part of the learner on the other side. Hence, Sheikh Al-Ardh (1984) maintains that IbnKhaldun differentiates between three major elements: awareness, comprehension and talent and he avers that awareness and comprehension are common features among all people whether educated or popular while "talent" comes as a result of long and hard practice that enables the person to acquire the scientific laws and principles of a given craft. (Ibn-Khaldun, 2001).

The researcher believes that Ibn-Khaldun concentrated mostly on the key pre-conditions for learner's learning especially when he discusses the nature of human thought to the extent that he reiterates that the nature of human thought involves the ceaseless search for knowledge and achievement. As a result, this distinct nature stimulates the learner to inquire, explore and search for knowledge. Ibn-Khaldun emphasizes the strong connection between education on one side and civilization and development on the other side as key contributing aspects to the spread and development of knowledge and sciences. Ibn-Khaldun, nevertheless, did not underestimate the important roles of the teacher who leads and moderate the educational process by means of specified roles and practices he/she should hold and perform. Therefore, Ibn-Khaldun stresses the importance of teacher preparation in the fields of content knowledge, content pedagogical knowledge which seem to agree with the most recent educational trends (Zamel, 2016).

Moreover, Ibn-Khaldun was concerned with the learner as a recipient of knowledge who has his/her own behaviors that should be appreciated and that learners must not be punished by violent actions. Such thoughts agree with current educational trends although IbnKhaldun deemphasized the learner's active involvement in lesson planning and lesson presentation with the help of his teachers "Sheikh ". On the other hand, IbnKhaldun stressed the importance of the content as a precondition for learning and thus he suggested valuable criteria for judging the content which should serve the learner when enabling him/her to acquire the talent for learning excellently through having certain factors that contribute to this acquisition of talent. Such insight goes in consistency with other educators such as Adman and Mahmud (2014), Hadad (2011), Marjeen (2016) who emphasized the acquisition of the talent by the learner as 
indicated by Ibn-Khaldun who gave a special emphasis to the learner's knowledge and his/her psychological disposition.

What are Ibn-Khaldun's most important educational views of excellence of education?

Educators have always discussed the most significant criteria and standards of excellence of effective education which are related to some variables including the teacher, the learner, the environment, methods of teaching, and the curriculum (Marjeen , 2016). In this regard, Ibn-Khaldun identifies a number of educational practices and criteria that should exist in order to secure the excellence of education. These include the following:

a) Teacher professional development: IbnKhaldun stresses that teachers should not stop learning anytime and they also need to look at the new elements in the various disciplines.

b) Teachers should possess certain cognitive and physical abilities and traits to meet the necessities of teaching as a profession.

c) Teachers' variation: This means that teaching as a profession needs a variety of teachers who have different types of skills and methods of teaching so as to help learners get the required talent for education. d) Teachers' cooperation: This means that teachers need to work cooperatively within a team-work strategy that strengthens their talent for education.

e) Teachers should try their best to recognize the individual differences between learners as each stage of development requires its own ability and skills.

f) Considering learners potential and abilities: Ibn-Khaldun stresses the importance of learner's potential which indicates that teachers should not give learners what might be higher than abilities.

g) Teachers should avoid using violence and coercion: Ibn-Khaldun affirms that using force and violence with learners harm them especially the young whose behaviors negatively affected by such violence and basically will affect their ability and talent to learn. Therefore, Ibn-Khaldun calls for positive humane interaction with learners.

h) Using innovative methods of teaching to pass knowledge to learners and building friendly rapport with students based on mutual respect .

i) Empoying a variety of teaching methods including debate, negotiation and discussion so as to minimize the use of traditional methods of teaching "talk and chalk". 


\section{International Journal of Advanced Multidisciplinary Scientific Research (IJAMSR) ISSN:2581-4281}

j) Emphsizing application stage in teaching: This means that teachers should pay special attention to the application phase of teaching as students need to apply what they learn in their daily life situations. Teachers then need to link theory with practice.

k) Teaching and knowledge dissemination should be gradual using logical and scientific methodology. This means that teaching should be gradual and repetitive to suit both the topic and the learners as well. Such ascending order involves the importance of taking into account learners' cognitive, psychological and knowledge abilities and this seems to agree with today's educators and psychologists.

1) Teachers should not move from one task or activity before they are certain that learners clearly understood the first task or material to avoid any possible lack of comprehension on the part of the learner.(Haddad, 2011).

m) Using sensory -based methods of teaching especially with beginners and avoiding using abstract teaching while emphasizing practical field activities which means that Ibn-Khaldun's vision of learning is so close to the practical point of view.(Haddad, 2011).

n) involving education to reality: Ibn-Khaldun believes that teachers "Sheikhs" need to use practical examples from the surrounding environment that help learners understand the teaching materials especially when these examples are very close to learners' daily life.
Such situation seems to be missing in our schools nowadays.

Hence, the researcher believes that Ibn-Khaldun's contributions to the basics of education fit his period and ours as well although there was no technological advancement at that time. Ibn-Khaldun strenuous on the major elements of the teaching-learning process from different angles especially teacher professional development, variation of methods of teaching and instruction, teaching competences, taking care of learners and their individual differences and abilities in addition to avoiding violence and coercion. Furthermore, we see that Ibn-Khaldun calls for using sensory aids when teaching young children. These issues and others constitute key topics and concepts in the teachinglearning process which agree with many studies relevant to the educational thought such as Adman and Mahmud (2014) which showed that methods of teaching and instruction is an industry (craft) by itself since it is based on educational vision. These thoughts also agree with Awamreh (2014) who emphasized the importance of taking care of learners' thoughts and abilities so as to adapt methods of teaching to suit learners' needs and interests in addition to their cognitive levels.

\section{Conclusion}

To sum up, the previous discussion reveals that IbnKhaldun was a great educator and intellectual who devoted his life and thoughts to innovative ideas and visions with regard to education. If we aim to analyze his insights of education and its major principles and 
practices, we need a very long study to cover all of these topics and concerns. consequently, the researcher limited his analysis and discussion to specific issues related to Ibn-Khaldun's educational visions and insights wherein he offered some educational criteria and standards that fit his time and ours as well regardless of the vast educational and technological advancement we have nowadays. Ibn-Khaldun's ideas, although go back to hundreds of years, paved the way for the current educational theories especially those relevant to methods of education and educational psychology. He also suggested some recommendations and criteria that aim to contribute to the objective of achieving quality of education. For example, Ibn-Khaldun identified some pre-conditions for learning which are relevant to human thought, civilization and development, teachers, learners, and the content as these elements considered to be major factors needed to acquire and strengthen the talent for learning among learners. Furthermore, Ibn-Khaldun, offered some suggestions for enhancing the quality of education such as teacher professional development and taking into account learners' individual differences, connecting education with reality and practice, using sensory -based methods of teaching especially when teaching young children as all of these elements contribute to teaching competences and agree with the most recent educational studies nowadays. Hence, it can be stated that Ibn-Khaldun's educational thought constitutes one major factor that paved the way for establishing the basic principles of education for today's schools in terms of preparation of teachers' content knowledge, pedagogical knowledge and professional competences including his methods of presenting the material and methods of interacting with learners while taking into account learners' individual differences and their desires to enhance teaching and learning at the same time. This means that Ibn-Khaldun's originality of thoughts contributed to the establishment of effective pedagogical criteria and methodology.

\section{Suggestions}

In light of the outcome of this analytical study, the researcher recommends the subsequent:

- Decision makers at the department of Education should modify the educational policy so as to provide them with new insight and vision resultant from Ibn-Khaldun's belief as shown in this diagnostic study.

- Educators, supervisors and teachers should benefit from the suggestions and enlightening recommendations which were emphasized by Ibn-Khaldun particularly those related to teacher training and his specialized and information competences, methods of presenting the material, pre-conditions for education, humane interface with learners, learners' individual differences, teaching competence, methods deviation and linking education to realism. 


\section{References}

1) Adman, A. \& Mahmud, A. (2014). "Concept of quality of education from the Islamic perspective. A study of terminology and content in Ibn-Khaldun's thought". IUG Journal of for educational and psychological Sciences. 22 (4), 147-174.

2) Akkawi, R. (1998), "Ibn Khaldun: The Most Famous Historian in Islam". First edition, Beirut, Lebanon, Daar al-Fikr Al-Arabi.

3) Al-Alawani, R. (2006)."Ibn-Khaldun's methodology for educational reformation. Seminar of IbnKhaldun's Thought and reformation call". Bahrin University 11/5/2006, 170-198.

4) Al-Bahi, M. and Fiadh, N.(2009). "Trends of higher education in light of comprehensive quality concept". $1^{\text {st }}$ edition. Cairo, Egyptian Anglo Bookshop.

5) Al-Khaldi, J. (2011), "Raising Children in Islam"". First edition, Amman, Jordan, Daar Wael for Publishing and Distribution.

6) AL-Sayyed, A. (2005), "Arab Scholars Encyclopaedia". $1^{\text {st }}$ edition, Al-Ahliyya for Publishing and Distribution.

7) Awamreh, M. (2014)."Ibn Khaldoun's View of Knowledge Maturity". Journal of Education and Practice, 5(3), 1-7.

8) Froukh, O. (1984), "Arab Science History".. $4^{\text {th }}$ edition, Beirut, Lebanon, Daar Al-'Ilm li-- Malayeen.

9) Haddad, F. (2011). "Ibn-Khaldun and his pedagogical and linguistic thoughts "Analytical study ". Algeria , Publications of Lab of linguistic practices. Mawlud Muaamari University. Tizi Wazo.

10) Ibn-Khaldun, A. (2001). "Ibn-Khaldun's Muqaddimah .Diwan Al-Mubtada wa Al-Khabar in the history of Arabs and Gibbers and Elite people who live with them". Volume 1. Margins and indices control done by Khalil Shihadeh. Revised by Suhail Zakkar. Beirut, Dar Al-Fikr for Prints and Publications.

11) Marjeen, H.(2016). "Quality of education in IbnKhaldun's Muqaddimah". Al-Hiwar al-Mutamadin . retrieved December $23^{\text {rd }} 2016$ from:

http://www.ahewar.org/debat/show.art.asp?aid=503 559

12) Muhi, M. (1991). "The Khaldunic Approach: Towards An Arabic-Islamic Pedagogical Approach". Morocco, An-Najah Modern Printing shop.

13) Shams Eddeen, A. (1986). "Educational thought of Ibn-Khaldun and Ibn Al-Azraq". $2^{\text {nd }}$ edition. Encyclopaedia of Islamic Education .Beirut, Dar Iqraa for publications and Distribution.

14) Sheetah, M. (2007). "Future horizons for higher education and challenges of development in the Libyan community". Bangazi, National Bookstore (Dar Al-Kutub).
15) Sheikh Al-Ardh, T. (1984). "Education according to Ibn-Khaldun". Journal of Arabic Heritage, 15 \& 16, (86-87).

16) Zamel, M. (2016). "Suggested Perspectives of the $21^{\text {st }}$ century school in Palestine". Journal of Islamic University for Educational \& Psychological Sciences, 24(4), 48-73. 